\title{
Effects of Calcium Nitrate Levels and Soaking Durations on Cocopeat Nutrient Content
}

\author{
Sheku N. Gbollie* (D), Samuel M. Mwonga, Anthony M. Kibe \\ Department of Crops, Horticulture and Soils, Faculty of Agriculture, Egerton University, Njoro, Kenya \\ Email: ^shekunyumahgbollie@gmail.com
}

How to cite this paper: Gbollie, S.N., Mwonga, S.M. and Kibe, A.M. (2021) Effects of Calcium Nitrate Levels and Soaking Durations on Cocopeat Nutrient Content. Journal of Agricultural Chemistry and Environment, 10, 372-388.

https://doi.org/10.4236/jacen.2021.103024

Received: July 2, 2021

Accepted: August 23, 2021

Published: August 26, 2021

Copyright (c) 2021 by author(s) and Scientific Research Publishing Inc. This work is licensed under the Creative Commons Attribution International License (CC BY 4.0).

http://creativecommons.org/licenses/by/4.0/

\begin{abstract}
Cocopeat, a by-product of the coconut (Cocos nucifera L.), is an important soilless media that contains high potassium $(\mathrm{K})$, sodium $(\mathrm{Na})$, and electrical conductivity (EC) depending on its source. Methods for extracting these elements and thus lowering EC are yet to be standardized. This study was therefore carried out to investigate two extraction methods of these elements in cocopeat. A greenhouse pot experiment was carried out at the Climate and Water Smart Agriculture Centre of Egerton University, Kenya. It was laid out in a $5 \times 4$ factorial completely randomized design. Five soaking durations (12, $24,36,48$, and 72 hours $)$ and four calcium nitrate $\left(\mathrm{Ca}\left(\mathrm{NO}_{3}\right)_{2}\right)$ levels $(0,60$, 100 , and $150 \mathrm{~g}$ ) were used. The experiment was done in two folds: the leachate and treated cocopeat examination for their chemical properties. The General Linear Model procedures were used for Analysis of Variance at $(\mathrm{P} \leq 0.05)$. The results showed that the addition of $\mathrm{Ca}\left(\mathrm{NO}_{3}\right)_{2} 100 \mathrm{~g}$ extracted significantly more $\mathrm{K}$ and $\mathrm{Na}$ in the leachate than $\mathrm{Ca}\left(\mathrm{NO}_{3}\right)_{2} 0.0 \mathrm{~g}$ and $60 \mathrm{~g}$. The $\mathrm{EC}$ levels in the leachate increased with the application levels of $\mathrm{Ca}\left(\mathrm{NO}_{3}\right)_{2}$ while the $\mathrm{pH}$ levels were reducing. In the treated cocopeat, $\mathrm{Ca}\left(\mathrm{NO}_{3}\right)_{2} 100 \mathrm{~g}$ and soaking duration 36 hours significantly reduced $\mathrm{K}$ and $\mathrm{Na}$ and sufficiently supplemented $\mathrm{Ca}$ and $\mathrm{N}$. Irrespective of $\mathrm{Ca}\left(\mathrm{NO}_{3}\right)_{2}$ and soaking durations, after the cocopeat is washed, the $\mathrm{EC}$ and $\mathrm{pH}$ values fall within their suitable ranges. There was a strong negative correlation between $\mathrm{Ca}$ and $\mathrm{Na}, \mathrm{Ca}$ and $\mathrm{K}$, and between $\mathrm{Na}$ and EC. Also, strong positive correlation between $\mathrm{Ca}$ and $\mathrm{N}$ and $\mathrm{Ca}$ and EC. Effective supplementation of $\mathrm{Ca}$ and $\mathrm{N}$, and optimal reduction of $\mathrm{K}$ and $\mathrm{Na}$ by $78.44 \%$ and $92 \%$, respectively can be achieved with $100 \mathrm{~g}$ of $\mathrm{Ca}\left(\mathrm{NO}_{3}\right)_{2} 1.5 \mathrm{~kg}^{-1}$ of cocopeat in 15 liters of water with a soaking duration of 36 hours.
\end{abstract}

\section{Keywords}

Calcium Nitrate, Cocopeat, Leachate, Potassium, Soaking 


\section{Introduction}

Cocopeat, also known as coconut (Cocos nucifera L.) fiber, coir, coir pith or coir dust, it is an organic planting media made from coconut husk that surrounds the shell of the coconut [1] [2]. Generally, cocopeat contains high K, Na, and EC but the concentrations vary with sources [3]. The husks are used to produce various types of growing substrates, including cocopeat, chips, and chunks [4]. Out of the total annual global production of coconut 62.8 million tonnes, only $10 \%$ of the coconut husks are being used for cocopeat extraction amounting to an estimate of 1.5 million metric tonnes [5] [6]. The importance of cocopeat cannot be overemphasized; it has an ideal $\mathrm{pH}$, holds more than $22 \%$ air, and has excellent drainage properties. Its anti-fungicidal properties help plants to get rid of soil-borne diseases, and it is $100 \%$ renewable, easy to hydrate, has little or no weed, and is environmentally friendly [7] [8]. In Kenya, the total area covered by coconut was estimated at 82,921 and 84,824 hectares in 2018 and 2019, respectively and this was mainly in the coastal regions [5] [6].

Soilless culture has become one of the prominent means to achieve higher productivity around the globe. Regardless of cocopeat's importance, its use faces some challenges related to its chemical composition. The cation exchange capacity (CEC) of cocopeat is between $40-100 \mathrm{cmol} \cdot \mathrm{kg}^{-1}$ [8]. This means that cocopeat can hold onto nutrients, but it can also lock certain nutrients out, leading to deficiencies in the plants. Cocopeat's initial cation exchange sites are naturally saturated with $\mathrm{K}$ and $\mathrm{Na}$ with little or no calcium (Ca) [9] [10] [11] [12]. Potassium which is the dominant element in cocopeat can be attached up to between $38.5-40 \mathrm{cmol} \cdot \mathrm{kg}^{-1}$ of the total sites and $\mathrm{Na}$ at $13.04-15 \mathrm{cmol} \cdot \mathrm{kg}^{-1}$ of the total sites [11]. Through cation exchange, in the presence of $\mathrm{Ca}$, the sites will release their $\mathrm{Na}$ and $\mathrm{K}$ cations and lock onto $\mathrm{Ca}$. Coconut trees have a naturally high tolerance for sodium chloride [8]. Most coconuts are produced along the coast or on highly saline soils. The origin of cocopeat has an impact on its nutrient content as those produced away from the ocean may not accumulate as much $\mathrm{Na}$ and $\mathrm{K}$ compared to those grown along the coast [13]. The EC of an untreated cocopeat is usually $>1.0$ milli siemens per centimeter $\left(\mathrm{mS} \cdot \mathrm{cm}^{-1}\right)$. For hydroponics purposes, it is advisable to maintain $\mathrm{EC}<1.0 \mathrm{mS} \cdot \mathrm{cm}^{-1}$ [12]. For maximum utilization of cocopeat for crop production, efforts must be made to reduce the high level of $\mathrm{K}$ and $\mathrm{Na}$ in cocopeat. Reducing the high level of $\mathrm{K}$ in cocopeat reduces $\mathrm{K}$ toxicity, enhances Ca uptake by the plant, and stimulates crop root development leading to higher productivity of crops [14].

Several methods are used to treat cocopeat for $\mathrm{K}$ and $\mathrm{Na}$ optimization: water, with and without $\mathrm{Ca}\left(\mathrm{NO}_{3}\right)_{2}$, magnesium nitrate, and barium chloride [11] [13] [15]. Although water or $\mathrm{Ca}\left(\mathrm{NO}_{3}\right)_{2}$ alone cannot extract the naturally bonded $\mathrm{K}$ and $\mathrm{Na}$, when used simultaneously, the effects are observed. Most local cocopeat producers are randomly treating cocopeat with water and some are adding $\mathrm{Ca}\left(\mathrm{NO}_{3}\right)_{2}$ at different levels to reduce $\mathrm{K}$ and $\mathrm{Na}$. The use of $\mathrm{Ca}\left(\mathrm{NO}_{3}\right)_{2}$ reduces elements that are naturally bonded to the cation exchange complex of cocopeat [8] [11]. The 
main goal of treating cocopeat is to reduce the quantity of $\mathrm{K}$ and $\mathrm{Na}$ and supplement with $\mathrm{Ca}$ and $\mathrm{N}$. Using untreated cocopeat to grow crops creates a very unsuitable growth medium for many horticultural plants. When the untreated cocopeat is used for crop production, $\mathrm{K}$ and $\mathrm{Na}$ develop a stronger attraction to the peat's complex causing nutrient lockout for other elements. This causes $\mathrm{K}$ and $\mathrm{Na}$ to be displaced into the solution and be taken up by the plants instead of $\mathrm{Ca}$. The objective of this study was to determine the ratio of $\mathrm{Ca}\left(\mathrm{NO}_{3}\right)_{2}$ to cocopeat and soaking duration suitable for $\mathrm{K}, \mathrm{Na}$, and $\mathrm{EC}$ minimization while supplementing $\mathrm{Ca}$ and $\mathrm{N}$ in cocopeat.

\section{Materials and Methods}

\subsection{Determination of Chemical Properties of Cocopeat and Water Used}

Initially, the untreated cocopeat sourced from Cocoponics Africa Limited, and water that was used to soak the cocopeat were analyzed at the Kenya National Agricultural Research Laboratory (NARL)-Kabete for $\mathrm{K}, \mathrm{Na}, \mathrm{Ca}, \mathrm{N}, \mathrm{EC}$, and $\mathrm{pH}$. The quality of water was evaluated because it affects the exchange reactions of $\mathrm{K}$, $\mathrm{Na}$ and $\mathrm{Ca}$ on the adsorption complex of cocopeat [15]. The pH and EC were determined using a 1:2.0 (w/v) ratio of media to water suspension using a $\mathrm{pH}$ meter and conductivity meter for EC [16]. Total N, Ca, Na and K were extracted using concentrated $96 \%$ sulfuric acid $\left(\mathrm{H}_{2} \mathrm{SO}_{4}\right)$, salicylic acid $\left(\mathrm{C}_{7} \mathrm{H}_{6} \mathrm{O}_{3}\right)$, hydrogen peroxide $30 \%$, and selenium powder. Using the Kjeldahl digestion method as in [17] for total $\mathrm{N}$ determination, samples of the substrates were dried in an oven at $70^{\circ} \mathrm{C}$ and oxidized with hydrogen peroxide $30 \%$ at a relatively low temperature $\left(100^{\circ} \mathrm{C}\right)$. After decomposition of the excess $\mathrm{H}_{2} \mathrm{O}_{2}$ and evaporation of water, digestion was completed with a concentrated $96 \%$ sulphuric acid $\left(\mathrm{H}_{2} \mathrm{SO}_{4}\right)$ at elevated temperature $\left(330^{\circ} \mathrm{C}\right)$ under the influence of selenium powder as the catalyst. After the digested samples were cooled overnight, the exchangeable Ca was determined using an Atomic Absorption Spectrophotometer (AAS) at a wavelength $(\lambda)$ of $422.7 \mathrm{~nm}$, while exchangeable $\mathrm{K}$ and $\mathrm{Na}$ were determined using a flame photometer at $\lambda$ of $766 \mathrm{~nm}$ and $589 \mathrm{~nm}$, respectively [18] (Table 1).

Table 1. Chemical properties of the untreated cocopeat and water used.

\begin{tabular}{ccccccc}
\hline \multirow{2}{*}{ Properties } & $\mathrm{K}$ & $\mathrm{Na}$ & $\mathrm{Ca}$ & $\begin{array}{c}\text { Nitrogen } \\
\left(\mathrm{g}^{\mathrm{kg}} \mathrm{kg}^{-1}\right)\end{array}$ & $\begin{array}{c}\mathrm{EC} \\
\left(\mathrm{mS} \cdot \mathrm{cm}^{-1}\right)\end{array}$ & $\mathrm{pH}$ \\
\cline { 2 - 6 } Untreated cocopeat & 33.33 & 13.90 & 3.51 & 5.30 & 1.55 & 5.83 \\
Water & 0.03 & 0.09 & 0.003 & 0.00 & 0.52 & 7.7 \\
\hline
\end{tabular}

\subsection{Experimental Procedure and Treatments}

A greenhouse pot experiment, each of height $30 \mathrm{~cm}$, base diameter $28 \mathrm{~cm}$, and top diameter $28 \mathrm{~cm}$ was conducted at the Climate and Water Smart Agriculture Centre of Egerton University, Nakuru County, Kenya. The study site is situated 
at $0^{\circ} 22^{\prime} \mathrm{S}, 35^{\circ} 36^{\prime} \mathrm{E}$ at an altitude of 2267 meters above sea level. The experimental site is in agro-ecological zone III (medium potentials) with annual rainfall between 950 and $1500 \mathrm{~mm}$ [19]. At the experimental site, the average maximum and minimum ambient and greenhouse temperatures recorded were: $22.0^{\circ} \mathrm{C}$, $10.0^{\circ} \mathrm{C}$, and $30.0^{\circ} \mathrm{C}, 15.1^{\circ} \mathrm{C}$, respectively. The experiment was laid in a $5 \times 4 \mathrm{fac}-$ torial completely randomized design with 20 treatments and three replicates. Each replicate had 40 soaking pots (two pots treatment ${ }^{-1}$ ). The treatments were five soaking durations $\left(12,24,36,48\right.$, and 72 hours) and four levels of $\mathrm{Ca}\left(\mathrm{NO}_{3}\right)_{2}$ $(0,60,100$, and $150 \mathrm{~g})$ mixed with $1.50 \mathrm{~kg}$ of cocopeat in $15.0 \mathrm{~L}$ of water (Table 2).

The mixtures were then soaked for their respective soaking durations. After every six hours, each treatment was mixed and the leachate was collected after the respective soaking durations. Cocopeat media was then well rinsed using hydrogen peroxide $\left(\mathrm{H}_{2} \mathrm{O}_{2}\right)(0.5 \mathrm{~mL}$ into one litre of tap water) as means of eliminating any harmful pest [20]. Each treatment was rinsed using ten litres of the $\mathrm{H}_{2} \mathrm{O}_{2}$ solution. A second rinsing was done with five litres of tap water (without

Table 2. Treatments combination for the leachate and treated cocopeat experiment.

\begin{tabular}{|c|c|c|}
\hline Treatments & Grams of $\mathrm{Ca}\left(\mathrm{NO}_{3}\right)_{2}$ pot $^{-1}$ & Soaking durations (hours) \\
\hline C0D1 & 0 & 12 \\
\hline $\mathrm{C} 0 \mathrm{D} 2$ & 0 & 24 \\
\hline C0D3 & 0 & 36 \\
\hline C0D4 & 0 & 48 \\
\hline C0D5 & 0 & 72 \\
\hline C1D1 & 60 & 12 \\
\hline $\mathrm{C} 1 \mathrm{D} 2$ & 60 & 24 \\
\hline C1D3 & 60 & 36 \\
\hline C1D4 & 60 & 48 \\
\hline C1D5 & 60 & 72 \\
\hline $\mathrm{C} 2 \mathrm{D} 1$ & 100 & 12 \\
\hline $\mathrm{C} 2 \mathrm{D} 2$ & 100 & 24 \\
\hline $\mathrm{C} 2 \mathrm{D} 3$ & 100 & 36 \\
\hline $\mathrm{C} 2 \mathrm{D} 4$ & 100 & 48 \\
\hline C2D5 & 100 & 72 \\
\hline C3D1 & 150 & 12 \\
\hline $\mathrm{C} 3 \mathrm{D} 2$ & 150 & 24 \\
\hline C3D3 & 150 & 36 \\
\hline C3D4 & 150 & 48 \\
\hline C3D5 & 150 & 72 \\
\hline
\end{tabular}

Note: C0, C1, C2, C3: calcium nitrate 0, 60, 100, and 150 g, respectively. D1, D2, D3, D4, and D5: soaking durations $12,24,36,48$ and 72 hours, respectively. 
$\mathrm{H}_{2} \mathrm{O}_{2}$ ) for each treatment, and the media was left standing for 24 hours to drain the remaining water. Samples of the treated media in each treatment were taken for laboratory analyses.

\subsection{Data Collection}

After the respective soaking durations, the leachate for each treatment was collected and analysed for: $\mathrm{K}, \mathrm{Na}, \mathrm{EC}$, and $\mathrm{pH}$ levels. To determine the nutrient content in the treated cocopeat, samples of the treated cocopeat were also collected from each treatment and analysed for $\mathrm{K}, \mathrm{Ca}, \mathrm{Na}$, total $\mathrm{N}, \mathrm{EC}$, and $\mathrm{pH}$ levels (see Section 2.1).

\subsection{Data Analysis}

To meet the assumptions of Analysis of Variance (ANOVA), data were subjected to the normality test [21]. General Linear Model (GLM) procedures of the statistical analysis system (SAS), version 9.0 were used for ANOVA at $(\mathrm{P} \leq 0.05)$ [22]. Treatment means for the main effects of soaking duration and $\mathrm{Ca}\left(\mathrm{NO}_{3}\right)_{2}$ were separated using Tukey's Honestly Significant Difference (HSD) test at 0.05 level of significance. Pearson's Correlation test at $\mathrm{P} \leq 0.05$ was also performed between treated cocopeat elements extracted by the main effects of soaking duration and $\mathrm{Ca}\left(\mathrm{NO}_{3}\right)_{2}$. Microsoft Excel, 2015 was also used to develop graphs.

\section{Results}

\subsection{Initial Analyses for the Untreated Cocopeat and Water}

The results showed that the untreated cocopeat had excessive concentrations of $\mathrm{K}\left(33.33 \mathrm{cmol} \cdot \mathrm{kg}^{-1}\right)$ and $\mathrm{Na}\left(13.90 \mathrm{cmol} \cdot \mathrm{kg}^{-1}\right)$. The concentrations of $\mathrm{Ca}$ and total $\mathrm{N}$ were low while the EC was above the threshold of $1 \mathrm{mS} \cdot \mathrm{cm}^{-1}$, and the $\mathrm{pH}$ value was found to be in the suitable range of 5.5 - 6.5 (Table 1). In the water used, the $\mathrm{pH}$ was mildly alkaline, EC was $<1 \mathrm{mS} \cdot \mathrm{cm}^{-1}$. The critical nutrients in water were suitable to be used for the soaking of cocopeat as none was excessive.

\subsection{Effects of Calcium Nitrate Levels and Soaking Durations on the Chemical Properties of Cocopeat Leachate}

Other than $\mathrm{Na}$, no significant $(\mathrm{P}>0.05)$ interaction effect between $\mathrm{Ca}\left(\mathrm{NO}_{3}\right)_{2}$ and soaking duration was observed for $\mathrm{K}, \mathrm{EC}$, and $\mathrm{pH}$ in the cocopeat lactate. The results showed that $\mathrm{Ca}\left(\mathrm{NO}_{3}\right)_{2} 100 \mathrm{~g}$ significantly increased $\mathrm{K}$ in the leachate by $15.5 \%$, compared to $\mathrm{Ca}\left(\mathrm{NO}_{3}\right)_{2}(0.0 \mathrm{~g})$. Electrical conductivity levels increase with an increase in the application levels of the $\mathrm{Ca}\left(\mathrm{NO}_{3}\right)_{2}$. The highest rate of $\mathrm{Ca}\left(\mathrm{NO}_{3}\right)_{2}$ (150 g) increased the EC by $56.28 \%$ compared to the treatment with no $\mathrm{Ca}(\mathrm{NO} 3)_{2}$ application. On the other hand, $\mathrm{pH}$ was inversely proportional to the concentrations of $\mathrm{Ca}\left(\mathrm{NO}_{3}\right)_{2}$ and $\mathrm{EC}$ in the leachate. As the $\mathrm{Ca}\left(\mathrm{NO}_{3}\right)_{2}$ concentration increased, the $\mathrm{pH}$ values became more acidic to $\mathrm{pH} 5.88$ for the highest level of $\mathrm{Ca}\left(\mathrm{NO}_{3}\right)_{2}$ application (Table 3 ). Soaking duration did not significantly $(\mathrm{P}>0.05)$ influence $\mathrm{K}, \mathrm{EC}$, and $\mathrm{pH}$, but significant differences $(\mathrm{P}<0.05)$ were observed for $\mathrm{Na}$. 
Table 3. Means separation for the main effects of soaking duration and calcium nitrate on $\mathrm{K}, \mathrm{EC}$, and $\mathrm{pH}$ in the leachate.

\begin{tabular}{cccc}
\hline Soaking durations (hours) & $\mathrm{K}\left(\mathrm{cmol} \cdot \mathbf{k g}^{\mathbf{1}}\right)$ & $\mathrm{EC}\left(\mathrm{mS} \cdot \mathrm{cm}^{-1}\right)$ & $\mathrm{pH}$ \\
\hline 12 & $10.64^{\mathrm{a}}$ & $7.76^{\mathrm{a}}$ & $6.13^{\mathrm{a}}$ \\
24 & $11.18^{\mathrm{a}}$ & $7.87^{\mathrm{a}}$ & $6.06^{\mathrm{a}}$ \\
36 & $12.00^{\mathrm{a}}$ & $7.93^{\mathrm{a}}$ & $6.05^{\mathrm{a}}$ \\
48 & $10.66^{\mathrm{a}}$ & $8.01^{\mathrm{a}}$ & $6.09^{\mathrm{a}}$ \\
72 & $10.86^{\mathrm{a}}$ & $8.10^{\mathrm{a}}$ & $6.06^{\mathrm{a}}$ \\
$M S D$ & 2.78 & 0.63 & 0.13 \\
\hline Calcium nitrate (g) & $\mathrm{K}\left(\mathrm{cmol} \cdot \mathrm{kg}^{\mathrm{1}}\right)$ & $\mathrm{EC}\left(\mathrm{mS} \cdot \mathrm{cm}^{-1}\right)$ & $\mathrm{pH}$ \\
\hline 000 & $9.21^{\mathrm{b}}$ & $3.39^{\mathrm{d}}$ & $6.36^{\mathrm{a}}$ \\
100.0 & $11.04^{\mathrm{ab}}$ & $6.81^{\mathrm{c}}$ & $6.07^{\mathrm{b}}$ \\
150.0 & $12.59^{\mathrm{a}}$ & $9.42^{\mathrm{b}}$ & $6.00^{\mathrm{b}}$ \\
$M S D$ & $11.44^{\mathrm{ab}}$ & $12.12^{\mathrm{a}}$ & $5.88^{\mathrm{c}}$ \\
\hline
\end{tabular}

The means followed by the same letters in the same column are not significantly different using Tukeys' HSD test at $5 \%$ level of significance. $0.0,60.0,100$, and 150 gram of $\mathrm{Ca}\left(\mathrm{NO}_{3}\right)_{2}$ and $12,24,36,48$, and 72 soaking durations hours.

\subsection{Effects of Soaking Durations and Calcium Nitrate Levels on the Rate of Change of $\mathrm{K}, \mathrm{Na}, \mathrm{EC}$, and $\mathrm{pH}$ in the Leachate}

This section describes the rate of change of the measured parameter (K, Na, EC and $\mathrm{pH})$ with an increase in $\mathrm{Ca}\left(\mathrm{NO}_{3}\right)_{2}$ application-level at a given soaking duration, and the rate of change of the measured parameters with increasing soaking duration at a given $\mathrm{Ca}\left(\mathrm{NO}_{3}\right)_{2}$ level. The fastest decreasing rate of change $\left(-0.0024 \mathrm{cmol} \cdot \mathrm{kg}^{-1}\right)$ for $\mathrm{K}$ was observed in $\mathrm{Ca}\left(\mathrm{NO}_{3}\right)_{2} 100 \mathrm{~g}$ and the slowest rate of change ( $\left.-0.0006 \mathrm{cmol} \cdot \mathrm{kg}^{-1}\right)$ was in $\mathrm{Ca}\left(\mathrm{NO}_{3}\right)_{2} 0 \mathrm{~g}$ (Table 4) and (Figure 1(a)). In $\mathrm{Na}$, only $\mathrm{Ca}\left(\mathrm{NO}_{3}\right)_{2} 100 \mathrm{~g}$ gave a decreasing rate of change $\left(-0.0014 \mathrm{cmol} \cdot \mathrm{kg}^{-1}\right)$. The $\mathrm{Na}$ concentration in $0 \mathrm{~g}, 60 \mathrm{~g}$, and $150 \mathrm{~g} \mathrm{Ca}\left(\mathrm{NO}_{3}\right)_{2}$ were increasing as durations increased. The highest rate of change for $\mathrm{Na}$ was in $0 \mathrm{~g}$ and the least was in $60 \mathrm{~g}$ of $\mathrm{Ca}\left(\mathrm{NO}_{3}\right)_{2}$ (Figure $1(\mathrm{~b})$ ). Although, there was no significant rate of change in the $\mathrm{pH}$ and the $\mathrm{EC}$ with increase in the soaking duration, the rate of change for EC was high in $60 \mathrm{~g}$ and low in $100 \mathrm{~g}$. On the other hand, the rate of change for $\mathrm{pH}$ in the leachate was high in $100 \mathrm{~g}(-0.002)$ and low in $150 \mathrm{~g}$ of $\mathrm{Ca}\left(\mathrm{NO}_{3}\right)_{2}$ (Figure $1(\mathrm{c})$ and Figure $1(\mathrm{~d})$ ).

\subsection{Effects of Calcium Nitrate Levels and Soaking Durations on Chemical Properties of the Treated Cocopeat}

Amongst the parameters examined, the interaction between $\mathrm{Ca}\left(\mathrm{NO}_{3}\right)_{2} \times$ soaking duration was only observed for $\mathrm{N}$. No interaction effect was observed for $\mathrm{K}, \mathrm{Na}$, $\mathrm{Ca}, \mathrm{EC}$, and $\mathrm{pH}$ in the treated cocopeat. The main effects for $\mathrm{Ca}\left(\mathrm{NO}_{3}\right)_{2}$ showed that there was a significant inverse relationship between $\mathrm{Ca}\left(\mathrm{NO}_{3}\right)_{2}$ levels 
Table 4. Interaction effects of calcium nitrate $\times$ soaking duration on the rate of change of $\mathrm{K}, \mathrm{Na}, \mathrm{EC}$, and $\mathrm{pH}$ in the lactate.

\begin{tabular}{|c|c|c|c|c|}
\hline $\mathrm{Ca}\left(\mathrm{NO}_{3}\right)_{2}(\mathrm{~g})$ & Element & Equation & $\mathbf{R}^{2}$ & Rate of change \\
\hline 150 & K & $y=-0.0005 x^{2}+0.0128 x+11.886$ & 0.5812 & -0.0010 \\
\hline 60 & & $y=-0.0008 x^{2}+0.0675 x+9.9453$ & 0.5725 & -0.0016 \\
\hline 100 & & $y=-0.0012 x^{2}+0.0874 x+11.432$ & 0.2200 & -0.0024 \\
\hline 0 & & $y=-0.0003 x^{2}+0.0548 x+7.5946$ & 0.7001 & -0.0006 \\
\hline 150 & $\mathrm{Na}$ & $y=0.0009 x^{2}-0.1224 x+9.8904$ & 0.8045 & 0.0018 \\
\hline 100 & & $y=-0.0007 x^{2}+0.0092 x+8.321$ & 0.6349 & -0.0014 \\
\hline 60 & & $y=0.0006 x^{2}-0.0421 x+6.3371$ & 0.3789 & 0.0012 \\
\hline 0 & & $y=0.0011 x^{2}-0.048 x+3.2754$ & 0.9363 & 0.0022 \\
\hline 150 & $\mathrm{EC}$ & $y=-0.0036 x+12.257$ & 0.3778 & -0.0036 \\
\hline 100 & & $y=0.0011 x+9.3748$ & 0.0105 & 0.0011 \\
\hline 60 & & $y=0.0155 x+6.2097$ & 0.444 & 0.0155 \\
\hline 0 & & $y=0.0052 x+3.191$ & 0.6531 & 0.0052 \\
\hline 0 & $\mathrm{pH}$ & $y=-0.0017 x+6.4223$ & 0.3701 & -0.0017 \\
\hline 60 & & $y=0.0007 x+6.0432$ & 0.1205 & 0.00070 \\
\hline 100 & & $y=-0.002 x+6.0741$ & 0.3917 & -0.0020 \\
\hline 150 & & $y=-8 E-05 x+5.8804$ & 0.0057 & $-8 \mathrm{E}-050$ \\
\hline
\end{tabular}
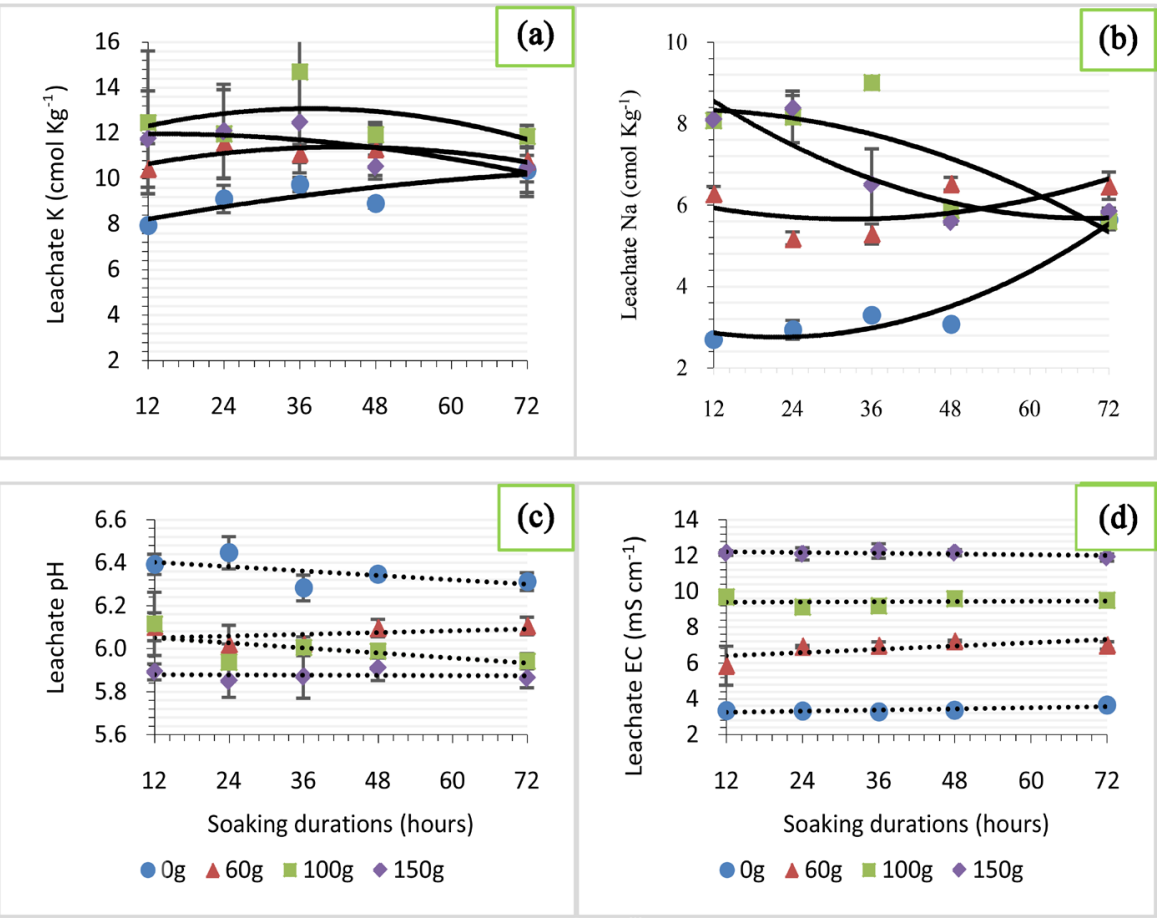

Figure 1. Effects of soaking durations and calcium nitrate levels on the rate of change of $\mathrm{K}, \mathrm{Na}, \mathrm{pH}$ and $\mathrm{EC}$ in cocopeat leachate. 
versus $\mathrm{K}$ and $\mathrm{Na}$ while a direct relationship was observed between $\mathrm{Ca}\left(\mathrm{NO}_{3}\right)_{2}$ levels versus $\mathrm{Ca}$ and $\mathrm{EC}$ in the treated cocopeat (Table 5). Both $\mathrm{Ca}\left(\mathrm{NO}_{3}\right)_{2}$ levels and soaking durations did not significantly $(\mathrm{P}>0.05)$ differ for $\mathrm{pH}$ in the treated cocopeat. The highest concentrations of $\mathrm{K}$ and $\mathrm{Na}$ were observed in $\mathrm{Ca}\left(\mathrm{NO}_{3}\right)_{2}$ $(0.0 \mathrm{~g})$ while the least concentrations of the two elements were found in the treatment receiving the highest level of $\mathrm{Ca}\left(\mathrm{NO}_{3}\right)_{2}(150 \mathrm{~g})$ Similarly, the highest $\mathrm{Ca}\left(58.17 \mathrm{cmol} \cdot \mathrm{kg}^{-1}\right)$ and EC $\left(0.98 \mathrm{mS} \cdot \mathrm{cm}^{-1}\right)$ were observed in the highest $\mathrm{Ca}\left(\mathrm{NO}_{3}\right)_{2}$ rate of $150 \mathrm{~g}$, followed by $100 \mathrm{~g}, 60 \mathrm{~g}$, and least from the treatments where $\mathrm{Ca}\left(\mathrm{NO}_{3}\right)_{2}$ was not applied. Soaking durations were also significantly $(\mathrm{P}<$ 0.001 ) different for $\mathrm{K}, \mathrm{Na}, \mathrm{Ca}$, total $\mathrm{N}$ and EC. Soaking duration 12 hours had $9.8 \%$ and $10.9 \%$ more $\mathrm{K}$ than soaking durations 48 and 72 hours, respectively. Although durations $24,36,48$, and 72 hours were not significantly different, a similar trend was observed for Na. The concentration of Ca was high in 72 and 48 hours (32.12 and $29.60 \mathrm{cmol} \cdot \mathrm{kg}^{-1}$ ), respectively and low in 12 and 24 hours (22.63 and $24.25 \mathrm{cmol} \cdot \mathrm{kg}^{-1}$ ), respectively. Electrical conductivity was below the threshold of $1 \mathrm{mS} \cdot \mathrm{cm}^{-1}$ after the cocopeat was treated in both the main effects of $\mathrm{Ca}\left(\mathrm{NO}_{3}\right)_{2}$ levels and soaking durations.

\subsection{Effect of Soaking Durations and Calcium Nitrate Levels on the Rate of Change of $\mathrm{K}, \mathrm{Ca}, \mathrm{Na}$, Total $\mathrm{N}$ and $\mathrm{EC}$ in the Treated Cocopeat}

The results showed that there was an increasing rate of change for $\mathrm{Ca}, \mathrm{N}$, and $\mathrm{EC}$

Table 5. Means separation for the main effects of soaking duration and calcium nitrate on $\mathrm{K}, \mathrm{Ca}, \mathrm{Na}, \mathrm{EC}$, and $\mathrm{pH}$ in treated cocopeat.

\begin{tabular}{|c|c|c|c|c|c|}
\hline \multirow{2}{*}{$\begin{array}{c}\text { Soaking } \\
\text { durations (hours) }\end{array}$} & $\mathrm{K}$ & $\mathrm{Ca}$ & $\mathrm{Na}$ & \multirow{2}{*}{$\begin{array}{c}\mathrm{EC} \\
\left(\mathrm{mS} \cdot \mathrm{cm}^{-1}\right)\end{array}$} & \multirow{2}{*}{$\mathrm{pH}$} \\
\hline & \multicolumn{3}{|c|}{$\left(\mathrm{cmol} \cdot \mathrm{kg}^{-1}\right)$} & & \\
\hline 12 & $13.33^{\mathrm{a}}$ & $22.63^{\mathrm{b}}$ & $1.52^{\mathrm{a}}$ & $0.64^{\mathrm{c}}$ & $5.67^{\mathrm{a}}$ \\
\hline 24 & $11.65^{\mathrm{ab}}$ & $24.25^{\mathrm{b}}$ & $1.39^{\mathrm{ab}}$ & $0.69^{\mathrm{bc}}$ & $5.71^{\mathrm{a}}$ \\
\hline 36 & $11.37^{\mathrm{ab}}$ & $26.90^{\mathrm{ab}}$ & $1.29^{\mathrm{bc}}$ & $0.70^{\mathrm{b}}$ & $5.68^{\mathrm{a}}$ \\
\hline 48 & $10.09^{\mathrm{b}}$ & $29.60^{\mathrm{a}}$ & $1.22^{\mathrm{c}}$ & $0.72^{\mathrm{ab}}$ & $5.68^{\mathrm{a}}$ \\
\hline 72 & $9.72^{\mathrm{b}}$ & $32.12^{\mathrm{a}}$ & $1.16^{\mathrm{c}}$ & $0.78^{\mathrm{a}}$ & $5.67^{\mathrm{a}}$ \\
\hline$M S D$ & 1.98 & 5.30 & 0.15 & 0.06 & 0.16 \\
\hline \multirow{2}{*}{ Calcium nitrate (g) } & $\mathbf{K}$ & $\mathrm{Ca}$ & $\mathrm{Na}$ & \multirow{2}{*}{$\begin{array}{c}\mathrm{EC} \\
\left(\mathrm{mS} \cdot \mathrm{cm}^{-1}\right)\end{array}$} & \multirow{2}{*}{$\mathrm{pH}$} \\
\hline & \multicolumn{3}{|c|}{$\left(\mathrm{cmol} \cdot \mathrm{kg}^{-1}\right)$} & & \\
\hline 0.0 & $19.59^{\mathrm{a}}$ & $3.60^{\mathrm{d}}$ & $1.97^{\mathrm{a}}$ & $0.48^{\mathrm{d}}$ & $5.68^{\mathrm{a}}$ \\
\hline 60.0 & $11.28^{\mathrm{b}}$ & $15.03^{\mathrm{c}}$ & $1.57^{\mathrm{b}}$ & $0.63^{\mathrm{c}}$ & $5.70^{\mathrm{a}}$ \\
\hline 100.0 & $7.09^{c}$ & $31.60^{\mathrm{b}}$ & $1.07^{\mathrm{c}}$ & $0.73^{\mathrm{b}}$ & $5.68^{\mathrm{a}}$ \\
\hline 150.0 & $6.96^{\mathrm{c}}$ & $58.17^{\mathrm{a}}$ & $0.67^{\mathrm{d}}$ & $0.98^{\mathrm{a}}$ & $5.66^{\mathrm{a}}$ \\
\hline$M S D$ & 1.66 & 4.45 & 0.13 & 0.05 & 0.14 \\
\hline
\end{tabular}

The means followed by the same letters within the same column are not significantly different using Tukeys' honestly significant difference test at $5 \%$ level of significance. MSD: minimum significant difference. 
Table 6. Interaction effects of calcium nitrate and soaking duration on the rate of change of $\mathrm{Ca}, \mathrm{K}, \mathrm{Na}, \mathrm{N}$, and $\mathrm{EC}$ in the treated cocopeat.

\begin{tabular}{|c|c|c|c|c|}
\hline $\mathrm{Ca}\left(\mathrm{NO}_{3}\right)_{2}(\mathrm{~g})$ & Element & Equation & $\mathbf{R}^{2}$ & Rate of change \\
\hline 150 & $\mathrm{Ca}$ & $y=0.2609 x+48.149$ & 0.8939 & 0.2609 \\
\hline 100 & & $y=0.2697 x+21.243$ & 0.9630 & 0.2697 \\
\hline 60 & & $y=0.0843 x+11.797$ & 0.8891 & 0.0843 \\
\hline 0 & & $y=0.0466 x+1.8131$ & 0.4801 & 0.0466 \\
\hline 0 & $\mathrm{~K}$ & $y=-0.0728 x+22.384$ & 0.9520 & -0.0728 \\
\hline 60 & & $y=-0.0915 x+14.796$ & 0.9406 & -0.0915 \\
\hline 100 & & $y=-0.0496 x+8.9990$ & 0.9767 & -0.0496 \\
\hline 150 & & $y=-0.018 x+7.64710$ & 0.0921 & -0.018 \\
\hline 0 & $\mathrm{Na}$ & $y=-0.0066 x+2.2229$ & 0.8654 & -0.0066 \\
\hline 60 & & $y=-0.0082 x+1.8874$ & 0.9888 & -0.0052 \\
\hline 100 & & $y=-0.0052 x+1.2647$ & 0.8426 & -0.0052 \\
\hline 150 & & $y=-0.0035 x+0.8015$ & 0.4956 & -0.0035 \\
\hline 150 & $\mathrm{~N}$ & $y=0.0533 x+10.245$ & 0.8098 & 0.0533 \\
\hline 100 & & $y=0.0307 x+7.309$ & 0.9631 & 0.0307 \\
\hline 60 & & $y=0.013 x+6.3027$ & 0.8838 & 0.0130 \\
\hline 0 & & $y=0.0045 x+4.9937$ & 0.5560 & 0.0045 \\
\hline 150 & EC & $y=0.0031 x+0.8644$ & 0.7032 & 0.0031 \\
\hline 100 & & $y=0.0021 x+0.65$ & 0.9725 & 0.0021 \\
\hline 60 & & $y=0.0006 x+0.6045$ & 0.9549 & 0.0006 \\
\hline 0 & & $y=0.0032 x+0.356$ & 0.9254 & 0.0032 \\
\hline
\end{tabular}

while a decreasing rate of change was observed for $\mathrm{K}$ and $\mathrm{Na}$ due to the effects of $\mathrm{Ca}\left(\mathrm{NO}_{3}\right)_{2}$ and soaking durations (Table 6). In $\mathrm{Ca}$, the highest rate of change $\left(0.2697 \mathrm{cmol} \cdot \mathrm{kg}^{-1}\right)$ was observed in $100 \mathrm{~g}$ of $\mathrm{Ca}\left(\mathrm{NO}_{3}\right)_{2}$ followed by $150 \mathrm{~g}, 60 \mathrm{~g}$, and $0.0 \mathrm{~g}$ giving the least rate of change $\left(0.0466 \mathrm{cmol} \cdot \mathrm{kg}^{-1}\right)$ (Figure $2(\mathrm{~d})$ ).

The rate of change in the total $\mathrm{N}$ was directly proportional to the concentration of $\mathrm{Ca}\left(\mathrm{NO}_{3}\right)_{2}$ levels with $150 \mathrm{~g}$ giving the highest $\left(0.0533 \mathrm{~g} \cdot \mathrm{kg}^{-1}\right)$ although not significantly different from $100 \mathrm{~g}$ of $\mathrm{Ca}\left(\mathrm{NO}_{3}\right)_{2}$ while $0 \mathrm{~g}$ give the least positive rate of change $\left(0.0045 \mathrm{~g}^{\mathrm{kg}} \mathrm{kg}^{-1}\right)$ (Figure $\left.2(\mathrm{c})\right)$. The EC rate of change was moderately high in $0.0 \mathrm{~g}$ and $150 \mathrm{~g}$ of $\mathrm{Ca}\left(\mathrm{NO}_{3}\right)_{2}\left(0.0032,0.0031 \mathrm{mS} \cdot \mathrm{cm}^{-1}\right)$, respectively and low in 60 $\mathrm{g}\left(0.0006 \mathrm{mS} \cdot \mathrm{cm}^{-1}\right)$ (Figure $2(\mathrm{e})$ ). For $\mathrm{K}$, the highest decreasing rate of change was observed in $60 \mathrm{~g}\left(-0.0915 \mathrm{cmol} \cdot \mathrm{kg}^{-1}\right)$ and the least was observed in $150 \mathrm{~g}(-0.018$ $\left.\mathrm{cmol} \cdot \mathrm{kg}^{-1}\right)$. As for $\mathrm{Na}$, the highest decreasing rate of change was in $0 \mathrm{~g}(-0.0066$ $\left.\mathrm{cmol} \cdot \mathrm{kg}^{-1}\right)$ while the least was in $150 \mathrm{~g}\left(-0.0035 \mathrm{cmol} \cdot \mathrm{kg}^{-1}\right)$.

\subsection{Pearson Correlation for the Main Effects of Calcium Nitrate and Soaking Duration on the Nutrient Content in the Treated Cocopeat}

The Pearson correlation test for the main effect of soaking duration revealed 


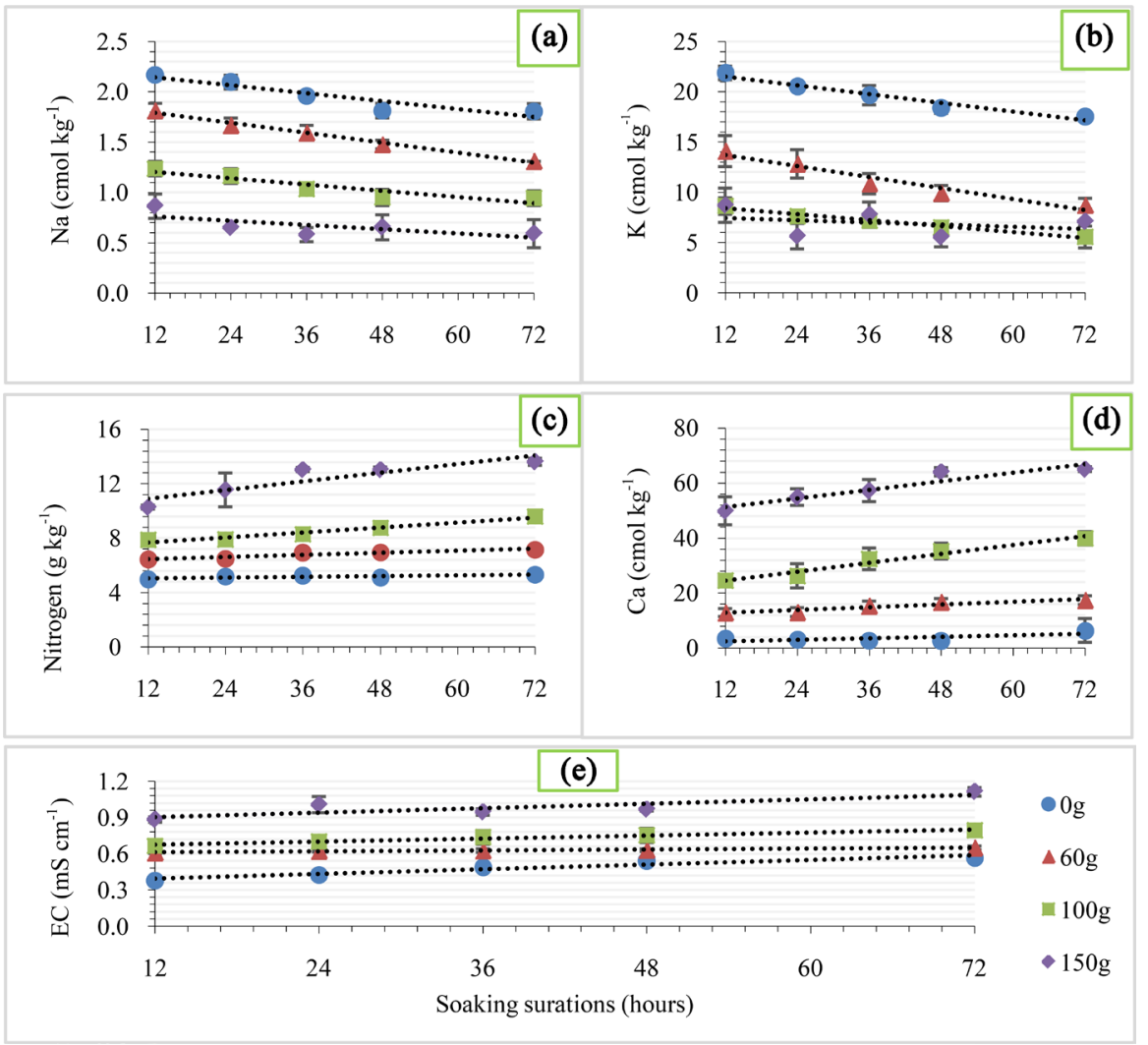

Figure 2. Effects of soaking durations and calcium nitrate levels on the rate of change of $\mathrm{Na}, \mathrm{K}, \mathrm{N}, \mathrm{Ca}$, and EC in the treated cocopeat.

Table 7. Pearson correlation coefficients of soaking durations between the treated cocopeat nutrients.

\begin{tabular}{cccccc}
\hline & $\mathbf{N}$ & $\mathbf{K}$ & $\mathrm{Ca}$ & $\mathrm{Na}$ & EC \\
\hline $\mathrm{K}$ & $-0.83^{\mathrm{ns}}$ & - & - & - & - \\
$\mathrm{Ca}$ & $0.87^{*}$ & $-0.95^{*}$ & - & - & - \\
$\mathrm{Na}$ & $-0.92^{*}$ & $0.98^{* *}$ & $-0.97^{* *}$ & - & - \\
$\mathrm{EC}$ & $0.84^{\mathrm{ns}}$ & $-0.94^{*}$ & $0.95^{\star}$ & $-0.95^{*}$ & - \\
$\mathrm{pH}$ & $-0.28^{\mathrm{ns}}$ & $-0.07^{\mathrm{ns}}$ & $-0.36^{\mathrm{ns}}$ & $0.19^{\mathrm{ns}}$ & $-0.17^{\mathrm{ns}}$ \\
\hline
\end{tabular}

strong negative correlations between $\mathrm{Ca}$ and $\mathrm{K}\left(r=-0.95^{\star}\right)$, $\mathrm{Ca}$ and $\mathrm{Na}(r=$ $\left.-0.97^{\star *}\right), \mathrm{K}$ and EC $\left(r=-0.94^{\star}\right), \mathrm{Na}$ and EC $\left(r=-0.95^{\star}\right)$, and between total $\mathrm{N}$ and $\mathrm{Na}\left(r=-0.92^{\star}\right)$. On the other hand, strong positive significant correlations were also observed between $\mathrm{N}$ and $\mathrm{Ca}\left(r=0.87^{\star}\right), \mathrm{K}$ and $\mathrm{Na}\left(r=0.98^{\star *}\right)$, and between Ca and EC $\left(r=0.95^{\star}\right)$ (Table 7).

There was no strong significant $(\mathrm{P}>0.05)$ correlation between $\mathrm{pH}$ and the rest of the elements/properties in both the soaking durations and $\mathrm{Ca}\left(\mathrm{NO}_{3}\right)_{2}$ levels. The correlation for the main effect of $\mathrm{Ca}\left(\mathrm{NO}_{3}\right)_{2}$ also showed that there were strong significant negative correlations between $\mathrm{Ca}$ and $\mathrm{Na}\left(r=-0.98^{*}\right)$, EC and $\mathrm{Na}(r=-0.98)$, and between $\mathrm{N}$ and $\mathrm{Na}\left(r=-0.97^{\star}\right)$. Strong positive significant correlations were observed between $\mathrm{N}$ and $\mathrm{Ca}\left(r=0.99^{\star}\right), \mathrm{N}$ and $\mathrm{EC}\left(r=0.99^{\star}\right)$, 
Table 8. Pearson correlation coefficients of calcium nitrate levels between the treated cocopeat nutrients.

\begin{tabular}{cccccc}
\hline & $\mathrm{N}$ & $\mathrm{K}$ & $\mathrm{Ca}$ & $\mathrm{Na}$ & $\mathrm{EC}$ \\
\hline $\mathrm{K}$ & $-0.81^{\mathrm{ns}}$ & - & - & - & - \\
$\mathrm{Ca}$ & $0.99^{* *}$ & $-0.83^{\mathrm{ns}}$ & - & - & - \\
$\mathrm{Na}$ & $-0.97^{*}$ & $0.92^{\mathrm{ns}}$ & $-0.98^{*}$ & - & - \\
$\mathrm{EC}$ & $0.99^{* *}$ & $-0.85^{\mathrm{ns}}$ & $0.99^{* *}$ & $-0.98^{*}$ & - \\
$\mathrm{pH}$ & $-0.73^{\mathrm{ns}}$ & $-0.30^{\mathrm{ns}}$ & $-0.74^{\mathrm{ns}}$ & $0.65^{\mathrm{ns}}$ & $-0.68^{\mathrm{ns}}$ \\
\hline
\end{tabular}

and between Ca and EC $\left(r=0.99^{*}\right)$ (Table 8$)$.

\section{Discussion}

\subsection{Chemical Properties of the Untreated Cocopeat and Water Used}

The EC of the untreated cocopeat was above the threshold for hydroponics system production due to the high level of $\mathrm{Na}$ and $\mathrm{K}$. The untreated cocopeat $\mathrm{pH}$ was in a suitable range for hydroponics crops (5.5 - 6.5) [7] [23]. Therefore, $\mathrm{K}$, $\mathrm{Na}$ and EC were the major problems in the untreated cocopeat examined. Generally, the untreated cocopeat had high $\mathrm{K}$ and $\mathrm{Na}$ with low $\mathrm{N}$ and $\mathrm{Ca}$ as this has been reported by [10] [11] [12] [24]. The water used was suitable for treating cocopeat as it had low $\mathrm{K}, \mathrm{Na}$, and $\mathrm{EC}$ while the $\mathrm{pH}$ was basic.

\subsection{Effects of Calcium Nitrate Levels and Soaking Durations on the Chemical Properties of Cocopeat Leachate}

The leachate analysis was done to determine whether $\mathrm{Ca}\left(\mathrm{NO}_{3}\right)_{2}$ was capable of extracting excessive $\mathrm{K}$ and $\mathrm{Na}$ from cocopeat. The interaction effect of soaking duration $\times \mathrm{Ca}\left(\mathrm{NO}_{3}\right)_{2}$ was not observed in the leachate for $\mathrm{K}, \mathrm{EC}$, and $\mathrm{Ph}$ because the buffering process was not completed as washing needed to be done for the full effect to be observed. After soaking, it is recommended to wash the cocopeat for complete $\mathrm{K}$ and $\mathrm{Na}$ extraction to be effective [8]. Cocopeat with $\mathrm{Ca}\left(\mathrm{NO}_{3}\right)_{2} 100 \mathrm{~g}$ significantly extracted $\mathrm{K}$ and $\mathrm{Na}$ by $7.63 \%$ and $16.08 \%$, respectively more compared to the cocopeat without $\mathrm{Ca}\left(\mathrm{NO}_{3}\right)_{2}$ in the soaking solution. Lower extraction of $\mathrm{Na}$ was observed in $\mathrm{Ca}\left(\mathrm{NO}_{3}\right)_{2} 0.0 \mathrm{~g}$, soaking durations $12,24,36,48$, and 72 hours probably due to the use of water (without $\left.\mathrm{Ca}\left(\mathrm{NO}_{3}\right)_{2}\right)$ in the mixture. Other researchers have similarly reported that the addition of $\mathrm{Ca}\left(\mathrm{NO}_{3}\right)_{2}$ to the cocopeat increases the extraction of $\mathrm{K}$ and $\mathrm{Na}$ [8] [25]. The interaction effects showed that for effective extraction of $\mathrm{Na}$, both $\mathrm{Ca}\left(\mathrm{NO}_{3}\right)_{2}$ and soaking duration should be used simultaneously. Electrical conductivity is directly proportional to the concentration of dissolved ions in a sample [26]. Therefore, treatments with little and no $\mathrm{Ca}\left(\mathrm{NO}_{3}\right)_{2}$ had relatively low EC values. Neto and others [27] argued that when the concentration of $\mathrm{Ca}\left(\mathrm{NO}_{3}\right)_{2}$ increases, $\mathrm{EC}$ significantly increases in a solution. This occurs because the EC of a solution is influenced by the presence of either hydrogen or hydroxyl ions. The inverse relationship observed between $\mathrm{Ca}\left(\mathrm{NO}_{3}\right)_{2}$ and $\mathrm{pH}$ was due to the effect of ammonium present in the $\mathrm{Ca}\left(\mathrm{NO}_{3}\right)_{2}$. Excessive ammonium is known 
to acidify soils by decreasing the $\mathrm{pH}$ [28]. Even though there were significant differences between the levels of $\mathrm{pH}$ in the leachate, all the values were in the suitable $\mathrm{pH}$ range (5.5 - 6.5) [7] [23]. On the other hand, there was no significant difference amongst the soaking durations for $\mathrm{K}, \mathrm{EC}, \mathrm{pH}$. The length of time taken for full reaction to occur between $\mathrm{Ca}\left(\mathrm{NO}_{3}\right)_{2}$ versus $\mathrm{K}, \mathrm{Na}, \mathrm{EC}$, and $\mathrm{pH}$ may have occurred even earlier than 12 hours. A similar result was obtained by [29] who observed no significant $(\mathrm{P}>0.05)$ effect of soaking durations for $\mathrm{pH}$ in cocopeat. It is evident that irrespective of soaking durations, the application of $\mathrm{Ca}\left(\mathrm{NO}_{3}\right)_{2}$ extracts $\mathrm{K}$ and $\mathrm{Na}$ while increasing the $\mathrm{EC}$ and reducing the $\mathrm{pH}$ in the leachate.

\subsection{Effect of Soaking Durations and Calcium Nitrate Levels on the Rate of Change of $\mathrm{K}, \mathrm{Na}, \mathrm{EC}$ and $\mathrm{pH}$ in the Leachate}

Though the $\mathrm{K}$ in the leachate was high in treatments with higher $\mathrm{Ca}\left(\mathrm{NO}_{3}\right)_{2}$ indicating higher $\mathrm{K}$ extraction, these concentrations tend to reduce over time. The decreasing rate of change observed in $\mathrm{K}$ at $\mathrm{Ca}\left(\mathrm{NO}_{3}\right)_{2} 0.0 \mathrm{~g}, 60 \mathrm{~g}, 100 \mathrm{~g}$, and $150 \mathrm{~g}$ indicate that as soaking durations increase, the $\mathrm{K}$ present in the leachate tends to decrease. The rate of change in $100 \mathrm{~g}$ of $\mathrm{Ca}\left(\mathrm{NO}_{3}\right)_{2}$ was $32 \%$ faster than the rate of change in $0.0 \mathrm{~g}$ of $\mathrm{Ca}\left(\mathrm{NO}_{3}\right)_{2}$. The change in $\mathrm{Na}$ was decreasing with increasing with increase $\mathrm{Ca}\left(\mathrm{NO}_{3}\right)_{2}$ levels. There was no significant rate of change observed for $\mathrm{EC}$ and $\mathrm{pH}$ in the leachate. The changes in $\mathrm{EC}$ and $\mathrm{pH}$ do not require a long soaking duration.

\subsection{Effects of Calcium Nitrate Levels and Soaking Durations on the Nutrient Content in the Treated Cocopeat}

The inverse relationship between $\mathrm{Ca}\left(\mathrm{NO}_{3}\right)_{2}$ versus $\mathrm{K}$ and $\mathrm{Na}$ was due to their valences. As the concentration of $\mathrm{Ca}$ ions increases, the adsorption of $\mathrm{K}$ and $\mathrm{Na}$ decreases [15]. Ions adsorption on surfaces depends on several factors, such as the mineral surface structure, the valency, size and hydration of an ion. Divalent cations are expected to bind stronger to the negatively-charged surfaces than monovalent cations [30]. Hydrogen having the same valency as $\mathrm{K}$ and $\mathrm{Na}$ cannot replace them, as such, higher $\mathrm{K}$ was observed in treatments without $\mathrm{Ca}\left(\mathrm{NO}_{3}\right)_{2}$ as the buffering process was not effective. Less $\mathrm{K}$ was observed in treatments with $\mathrm{Ca}\left(\mathrm{NO}_{3}\right)_{2}$ after the leaching process, but the trend was inversely proportional to the concentration of $\mathrm{Ca}\left(\mathrm{NO}_{3}\right)_{2}$. Calcium nitrate levels $0.0 \mathrm{~g}$ and $60 \mathrm{~g}$ extracted less $\mathrm{K}$ compared to $\mathrm{Ca}\left(\mathrm{NO}_{3}\right)_{2} 100 \mathrm{~g}$ and $150 \mathrm{~g}$. This means that $\mathrm{Ca}\left(\mathrm{NO}_{3}\right)_{2} 100 \mathrm{~g}$ is the equilibrium point for $\mathrm{K}$ extraction. A similar trend was observed in $\mathrm{Ca}\left(\mathrm{NO}_{3}\right)_{2}$ levels for $\mathrm{Na}$. Calcium nitrate $0.0 \mathrm{~g}$ extracted less $\mathrm{Na}$, thus the $\mathrm{Na}$ concentration in the treated cocopeat was relatively higher compared to the treatment with $\mathrm{Ca}\left(\mathrm{NO}_{3}\right)_{2} 150 \mathrm{~g}$ and $100 \mathrm{~g}$. The hydration (soaking) effect which is one of the factors that affect $\mathrm{K}$ helps to detach $\mathrm{K}$ due to its low electrostatic force [31]. Potassium is subdued when competing with $\mathrm{Ca}$ (divalent cations) due to its monovalent ability. As observed in the leachate, $\mathrm{K}$ was extracted but was still attached in the cocopeat as such no significant difference was observed between the soaking durations treatments. Significant differences were observed only after the coco- 
peat was washed. For $\mathrm{K}$ extraction process to be fully completed, $\mathrm{Ca}\left(\mathrm{NO}_{3}\right)_{2}$ and water must be used, vigorous mixing and washing must be done after the soaking process. The movement of $\mathrm{K}$ in soils is largely by diffusion and this occurs more rapidly at adequate moisture levels. As observed by Afri-Sefa and others [32], moisture content greatly affects $\mathrm{K}$ availability since leaching is a source of $\mathrm{K}$ loss. The significant differences found in the $\mathrm{Ca}\left(\mathrm{NO}_{3}\right)_{2}$ levels for $\mathrm{Ca}$ and total $\mathrm{N}$ in the treated cocopeat occurred due to the application of $\mathrm{Ca}\left(\mathrm{NO}_{3}\right)_{2}$. The $\mathrm{Ca}$ in treatments with $\mathrm{Ca}\left(\mathrm{NO}_{3}\right)_{2} 150 \mathrm{~g}$ and $100 \mathrm{~g}$ was greater than $\mathrm{Ca}\left(\mathrm{NO}_{3}\right)_{2} 0.0 \mathrm{~g}$. While total $\mathrm{N}$ in treatments with $\mathrm{Ca}\left(\mathrm{NO}_{3}\right)_{2} 150 \mathrm{~g}$ and $100 \mathrm{~g}$ was also greater than $\mathrm{Ca}\left(\mathrm{NO}_{3}\right)_{2} 0.0$ g. Nitrogen was one of the main elements in the $\mathrm{Ca}\left(\mathrm{NO}_{3}\right)_{2}$ used for the extraction. Hence, its attraction was higher as the levels of $\mathrm{Ca}\left(\mathrm{NO}_{3}\right)_{2}$ increased. The higher exchange capacity of $\mathrm{N}$ and $\mathrm{Ca}$ was found with an increase in $\mathrm{Ca}\left(\mathrm{NO}_{3}\right)_{2}$ levels in the solution. Comparatively, higher EC $\left(1.11 \mathrm{mS} \cdot \mathrm{cm}^{-1}\right)$ was observed in the interaction of $\mathrm{Ca}\left(\mathrm{NO}_{3}\right)_{2} 150 \mathrm{~g} \times$ soaking duration 72 hours and $\mathrm{Ca}\left(\mathrm{NO}_{3}\right)_{2} 150 \mathrm{~g} \times$ soaking duration $24\left(1.01 \mathrm{mS} \cdot \mathrm{cm}^{-1}\right)$ due to the concentration of $\mathrm{Ca}\left(\mathrm{NO}_{3}\right)_{2}$. As observed in the leachate, the $\mathrm{EC}$ in these treatments were much higher compared to the other treatments. After the cocopeat was washed, the EC was significantly reduced. The levels of $\mathrm{Ca}\left(\mathrm{NO}_{3}\right)_{2}$ used gave significant differences on the amount of EC in the treated cocopeat. The concentration of EC was higher in $150,100,60$, and $0 \mathrm{~g}$ of $\mathrm{Ca}\left(\mathrm{NO}_{3}\right)_{2}$, respectively. Although, all the $\mathrm{EC}$ values were $<1.0 \mathrm{mS} \cdot \mathrm{cm}^{-1}$ as observed [13], a similar trend was shown in the durations (longer durations had higher EC, but $\left.<1.0 \mathrm{mS} \cdot \mathrm{cm}^{-1}\right)$. Addition of $\mathrm{Ca}\left(\mathrm{NO}_{3}\right)_{2}$

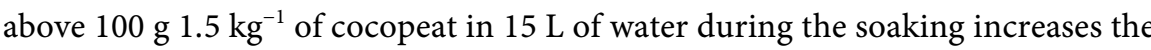
EC above $1 \mathrm{mS} \cdot \mathrm{cm}^{-1}$ in the treated cocopeat. After the cocopeat was washed, significant differences were observed among the durations for $\mathrm{K}, \mathrm{Ca}, \mathrm{Na}$, and EC. To achieve EC below $1 \mathrm{mS} \cdot \mathrm{cm}^{-1}$, cocopeat can be soaked without the addition of $\mathrm{Ca}\left(\mathrm{NO}_{3}\right)_{2}$ for economic reasons. The results obtained for $\mathrm{EC}$ and $\mathrm{pH}$ are in line with [33]. The extraction of $\mathrm{K}$ was lower in treatments with lower soaking durations. As the soaking durations increased, the extraction attained an equilibrium point. A similar trend was shown for Na. Soaking above 36 hours had no significant reduction of $\mathrm{Na}$ in cocopeat. In a nutshell, soaking durations did not reduce $\mathrm{K}$ and $\mathrm{Na}$ by a significant amount when soaked above 36 hours. Soaking duration 36 hours appears to be an equilibrium point for $\mathrm{K}, \mathrm{Ca}$, and $\mathrm{Na}$. Soaking below this point extracts less $\mathrm{K}$ and $\mathrm{Na}$, and soaking above will extract an insignificant amount to 36 hours. Also, $\mathrm{Ca}$ attraction attained its equilibrium at 36 hours as there was no significant difference above 36 hours.

\subsection{Effects of Soaking Durations and Calcium Nitrate Levels on the Rate of Change of $\mathrm{K}, \mathrm{Ca}, \mathrm{Na}$, Total $\mathrm{N}$ and $\mathrm{EC}$ in the Treated Cocopeat}

The increasing rate of change for $\mathrm{Ca}, \mathrm{N}$, and $\mathrm{EC}$ was due to the effect of $\mathrm{Ca}\left(\mathrm{NO}_{3}\right)_{2}$. As the soaking durations were increasing with fixed $\mathrm{Ca}\left(\mathrm{NO}_{3}\right)_{2}$ levels, the dissolved $\mathrm{Ca}\left(\mathrm{NO}_{3}\right)_{2}$ ions in the solution tend to increase the rate of reaction thereby increasing the $\mathrm{Ca}, \mathrm{N}$, and EC concentrations on the surfaces. Calcium was $34 \%$ 
faster in attraction in $\mathrm{Ca}\left(\mathrm{NO}_{3}\right)_{2} 100 \mathrm{~g}$ compared to $0.0 \mathrm{~g}$ of $\mathrm{Ca}\left(\mathrm{NO}_{3}\right)_{2}$. While total $\mathrm{N}$ attraction to the cocopeat was $49 \%$ and $26 \%$ faster in $\mathrm{Ca}\left(\mathrm{NO}_{3}\right)_{2} 150 \mathrm{~g}$ and 100 $\mathrm{g}$, respectively compared to $0.0 \mathrm{~g}$ of $\mathrm{Ca}\left(\mathrm{NO}_{3}\right)_{2}$. From the initial analyses, it was observed that $\mathrm{Ca}$ and $\mathrm{N}$ were limited in the cocopeat. As such, the supplementation of these elements through soaking is as essential as the fertilization of soil. On the other hand, the decreasing rate of change observed in $\mathrm{K}$ and $\mathrm{Na}$ was also due to the effect of cation exchange through $\mathrm{Ca}\left(\mathrm{NO}_{3}\right)_{2}$. Potassium and $\mathrm{Na}$ are known to be monovalent cations. In the presence of divalent cations $(\mathrm{Ca})$, the attraction of $\mathrm{K}$ and $\mathrm{Na}$ is expected to reduce while $\mathrm{Ca}$ increases [30]. Although the $\mathrm{K}$ extracted by $0.0 \mathrm{~g}$ and $60 \mathrm{~g}$ of $\mathrm{Ca}\left(\mathrm{NO}_{3}\right)_{2}$ was low, but the rate of reduction of $\mathrm{K}$ was much faster in treatments without low $\mathrm{Ca}\left(\mathrm{NO}_{3}\right)_{2}$ compared to treatment with $150 \mathrm{~g}$ of $\mathrm{Ca}\left(\mathrm{NO}_{3}\right)_{2}$. The rate of change was $31,39,21$, and $8 \%$ in 0,60 , 100 , and $150 \mathrm{~g}$ of $\mathrm{Ca}\left(\mathrm{NO}_{3}\right)_{2}$, respectively. A similar decreasing trend was observed for $\mathrm{Na}$ with $32,25,25$, and $17 \%$ in $0,60,100$, and $150 \mathrm{~g}$ of $\mathrm{Ca}\left(\mathrm{NO}_{3}\right)_{2}$, respectively. Though $\mathrm{Ca}\left(\mathrm{NO}_{3}\right)_{2}$ extracted more $\mathrm{K}$ and $\mathrm{Na}$, but the rate of extraction is much slower with higher concentrations.

\subsection{Pearson Correlation for the Main Effects of Calcium Nitrate Level and Soaking Duration on the Treated Cocopeat}

Some of the elements obtained from the effects of $\mathrm{Ca}\left(\mathrm{NO}_{3}\right)_{2}$ and soaking durations showed significant correlations. In both $\mathrm{Ca}\left(\mathrm{NO}_{3}\right)_{2}$ and soaking durations, there were strong significant negative correlations between $\mathrm{Ca}$ and $\mathrm{Na}$ and between $\mathrm{Na}$ and $\mathrm{N}$. These relationships showed as $\mathrm{Ca}$ and $\mathrm{N}$ increase, $\mathrm{Na}$ tend to reduce. In the soaking durations, there was also a strong significant $(\mathrm{P}<0.05)$ negative correlation between $\mathrm{Ca}$ and $\mathrm{K}$ which showed significant reduction of $\mathrm{K}$ as $\mathrm{Ca}$ increases. On the other hand, there was a significant positive correlation between $\mathrm{Ca}$ versus $\mathrm{N}$ and between $\mathrm{Ca}$ versus $\mathrm{EC}$ in both $\mathrm{Ca}\left(\mathrm{NO}_{3}\right)_{2}$ and soaking durations. The use of $\mathrm{Ca}\left(\mathrm{NO}_{3}\right)_{2}$ may have contributed to these relationships. The $\mathrm{Ca}\left(\mathrm{NO}_{3}\right)_{2}$ used was reached in $\mathrm{N}$ and $\mathrm{Ca}$, as such, as the concentration increases, $\mathrm{Ca}, \mathrm{N}$, and EC are expected to increase depicting a positive relationship. The salt content (EC) in a given sample is directly proportional to the concentration of dissolved ions [26]. Verhagen [15] found a significant positive correlation $\left(r=0.53^{* *}\right)$ between $\mathrm{K}$ and $\mathrm{Na}$ in the leachate. Kumar and others [34] also found a weak negative correlation $\left(-0.40^{\text {ns }}\right)$ between exchangeable $\mathrm{K}$ and $\mathrm{pH}$ in the soil.

\section{Conclusion}

The untreated cocopeat has high $\mathrm{K}, \mathrm{Na}$, and EC with limited $\mathrm{Ca}$ and $\mathrm{N}$ concentrations. Through the use of $\mathrm{Ca}\left(\mathrm{NO}_{3}\right)_{2}$, these excessive elements can be minimized while the limited elements are supplemented. In the leachate, $\mathrm{Ca}\left(\mathrm{NO}_{3}\right)_{2}$ is seen to have the ability for $\mathrm{K}$ and $\mathrm{Na}$ extraction while increasing the $\mathrm{EC}$ and reducing the $\mathrm{pH}$. After the cocopeat is soaked and washed, the $\mathrm{K}, \mathrm{Na}, \mathrm{Ca}, \mathrm{N}, \mathrm{EC}$, and $\mathrm{pH}$ are more responsive to the main effects of $\mathrm{Ca}\left(\mathrm{NO}_{3}\right)_{2}$ and soaking duration than the interaction effects of $\mathrm{Ca}\left(\mathrm{NO}_{3}\right)_{2} \times$ soaking duration. Comparatively, the single 
effect of $\mathrm{Ca}\left(\mathrm{NO}_{3}\right)_{2}$ extracted more $\mathrm{K}$ and $\mathrm{Na}$ compared to the single effect of soaking duration. The use of $100 \mathrm{~g} \mathrm{Ca}\left(\mathrm{NO}_{3}\right)_{2}$ significantly extracts $\mathrm{K}$ and $\mathrm{Na}$ in cocopeat. Although, $150 \mathrm{~g}$ of $\mathrm{Ca}\left(\mathrm{NO}_{3}\right)_{2}$ extract $\mathrm{Na}$ by $22.99 \%$ more than $100 \mathrm{~g}$ of $\mathrm{Ca}\left(\mathrm{NO}_{3}\right)_{2}$, the minimal ranges are significantly the same. Calcium and $\mathrm{N}$ significantly increase with an increase in $\mathrm{Ca}\left(\mathrm{NO}_{3}\right)_{2}$ up to $150 \mathrm{~g}$. After the cocopeat is washed, the $\mathrm{EC}$ and $\mathrm{pH}$ reduce within their suitable ranges irrespective of $\mathrm{Ca}\left(\mathrm{NO}_{3}\right)_{2}$ levels or soaking durations. Soaking duration 36 hours is an equilibrium point for $\mathrm{Ca}$ and $\mathrm{N}$ supplementation, and for $\mathrm{K}$ and $\mathrm{Na}$ extraction. Higher $\mathrm{Ca}$ and $\mathrm{N}$ supplementation in cocopeat is observed when $100 \mathrm{~g}$ of $\mathrm{Ca}\left(\mathrm{NO}_{3}\right)_{2}$ is used. On the other hand, $\mathrm{K}$ and $\mathrm{Na}$ tend to decrease faster in $0 \mathrm{~g}$ and $60 \mathrm{~g}$ compared to $100 \mathrm{~g}$ and $150 \mathrm{~g}$ of $\mathrm{Ca}\left(\mathrm{NO}_{3}\right)_{2}$. There is a strong negative correlation between Ca versus $\mathrm{Na}$, Ca versus $\mathrm{K}, \mathrm{Na}$ versus $\mathrm{N}$, and between Naversus EC. Also, there is a strong positive correlation between Ca versus $\mathrm{N}$, Ca versus $\mathrm{EC}$, and between $\mathrm{N}$ versus EC. For optimal reduction of $\mathrm{K}$ by $78.44 \%$ and for effective supplementation of $\mathrm{Ca}$ and $\mathrm{N}$ in cocopeat, $100 \mathrm{~g}$ of $\mathrm{Ca}\left(\mathrm{NO}_{3}\right)_{2} 1.5 \mathrm{~kg}^{-1}$ of cocopeat in 15 liters of water with a soaking duration of 36 hours is much effective. Sodium is also significantly reduced by $95.83 \%$ when $150 \mathrm{~g}$ is used and by $92.59 \%$ when $100 \mathrm{~g}$ of $\mathrm{Ca}\left(\mathrm{NO}_{3}\right)_{2}$ with a constant soaking duration of 36 hours. Information about the leachability of $\mathrm{K}$ and $\mathrm{Na}$ is important for the standardization of cocopeat for a variety of horticultural crops grown in a hydroponics system using cocopeat as a growing medium.

\section{Acknowledgements}

This research was funded by the Mastercard Foundation through the Regional Universities Forum for Capacity Building in Agriculture (RUFORUM) and Transforming African Agricultural Universities to meaningfully contribute to Africa's growth and development (TAGDev) program at Egerton University. The authors also wish to acknowledge the financial assistance of the Raise Your Hand Foundation (RYHF), United States of America.

\section{Conflicts of Interest}

The authors declare no conflicts of interest regarding the publication of this paper.

\section{References}

[1] Kimbonguila, A., Matos, L., Petit, J., Scher, J. and Nzikou, J.-M. (2019) Effect of Physical Treatment on the Physicochemical, Rheological and Functional Properties of Yam Meal of the Cultivar "Ngumvu" from Dioscorea alata L. of Congo. International Journal of Recent Scientific Research, 8, 19328-19334.

[2] Putra, F.P., Suparto, S.R. and Faozi, K. (2019) Relationship of Growth and Yield Mini Tubers of Potato Under. BERNAS Agricultural Research Journal, 15, 11-19.

[3] Abad, M., Noguera, P., Puchades, R., Maquieira, A. and Noguera, V. (2002) Physico-Chemical and Chemical Properties of Some Coconut Coir Dusts for Use as a Peat Substitute for Containerised Ornamental Plants. Bioresource Technology, 82, 
241-245. https://doi.org/10.1016/S0960-8524(01)00189-4

[4] Buechel, T. (2021) Coir as a Component of Growing Media. PRO-MIX, 1-6. https://www.pthorticulture.com/en/training-center/coir-a-component-of-growingmedia/

[5] FAOSTAT (2020) Statistical Database. Food and Agriculture Organization of the United Nations, Rome.

[6] AFA-NOCD (2020) The Coconut Value Chain Status. Agriculture and Food Authority (AFA), Nairobi.

[7] Schell, A. (2020) The Chemistry of Coco Coir. Maximum Yield. https://www.maximumyield.com/the-chemistry-of-coco-coir/2/2678

[8] Marock, D. (2021) How Do I Buffer Coco Peat: Buffering Coco Coir. Lichen Group, 1-10. https://www.lichengroup.co.za/buffering-coco-peat/

[9] Treder, J. (2008) The Effects of Cocopeat and Fertilization on the Growth and Flowering of Oriental lily "Star Gazer". Journal of Fruit and Ornamental Plant Research, $16,361-370$

[10] Sachin, T.M., Thakur, N. and Sharma, P. (2020) Use of Alternative Growing Media in Ornamental Plants. International Journal of Chemical Studies, 8, 188-194.

[11] Wittman, M. (2020) Buffering up Adjusting the Cation Exchange Capacity in Coco Growing Media. Maximum Yield, 2-5.

https://www.maximumyield.com/buffering-up-adjusting-the-cation-exchange-capa city-in-coco-growing-media/2/1318

[12] Halamba, S. and Kuack, D. (2021) Using Coir as a Growing Substrate. Hort Americas, 1-10. https://hortamericas.com/uncategorized/using-coir-as-growing-substrate/

[13] Poulter, R. (2014) Quantifying Differences between Treated and Untreated Coir Substrate. Acta Horticulturae, 1018, 557-564.

https://doi.org/10.17660/ActaHortic.2014.1018.61

[14] Shanmugasundaram, S., Jeyalakshmi, T., Sweatha, S.M., Saravanan, M., Goparaju, A. and Balakrishna, M. (2014) Coco Peat-An Alternative Artificial Soil Ingredient for the Earthworm Toxicity Testing. Journal of Toxicology and Environmental Health Sciences, 6, 5-12. https://doi.org/10.5897/JTEHS2013.0289

[15] Verhagen, J.B.G. (1999) CEC and the Saturation of the Adsorption Complex of Coir Dust. Acta Horticulture, 481, 151-158. https://doi.org/10.17660/ActaHortic.1999.481.14

[16] Cheng, C., Lehmann, J., Thies, J.E., Burton, S.D. and Engelhard, M.H. (2006) Oxidation of Black Carbon by Biotic and Abiotic Processes. Organic Geochemistry, 37, 1477-1488. https://doi.org/10.1016/j.orggeochem.2006.06.022

[17] Okalebo, J., Kenneth, R., Gathua, W. and Paul, L.W. (2002) Laboratory Methods of Soil and Plant Analysis: A Working Manual the Second Edition. 2nd Edition, Sacred Africa, Kenya Any, 1-131.

[18] Walinga, I., Van Der Lee, J., Houba, V. J., Vanvark, W. and Novozamsky, I. (1989) Plant Analysis Manual. Springer-Science, Berlin, 1-239.

[19] Jaetzold, R., Schmidt, H., Hornetz, B. and Shisanya, C. (2006) Farm Management Handbook of Kenya. Vol. II-Natural Conditions and Farm Management Information-2nd Edition Central Province. II. Ministry of Agriculture, Kenya, in Cooperation with the German Agency for Technical Cooperation (GTZ).

[20] Schmidt, L.J., Gaikowski, M.P. and Gingerich, W.H. (2006) Environmental Assessment for the Use of Hydrogen Peroxide in Aquaculture for Treating External Fun- 
gal and Bacterial Diseases of Cultured Fish and Fish Eggs. U.S. Geological Survey, Washington DC.

[21] Shapiro, A.S.S. and Wilk, M.B. (1965) An Analysis of Variance Test for Normality (Complete Samples). Biometrika, 52, 591-611.

https://doi.org/10.1093/biomet/52.3-4.591

[22] SAS Institute Inc. (2002) Cary, NC, USA. SAS Institute Inc., Cary.

[23] Mohammed, K. and Marzooqi, A. (2020) Date Palm Wastes as Growth Substrate in Hydroponics to Grow Lettuce (Lactuca sativa L.). United Arab Emirates University, College of Food and Agriculture, Department of Integrative Agriculture, Abu Dhabi.

[24] Gohil, P. (2018) Role of Growing Media for Ornamental Pot Plants. International Journal of Pure and Applied Bioscience, 6, 1219-1224. https://doi.org/10.18782/2320-7051.6218

[25] Bassett, P.A. (1980) The Effect of Soil Salinity and Calcium Levels on the Growth of Bromus, Mollis in the Camargue France. Jstor and Wiley, 35, 353-358. https://doi.org/10.2307/3544651

[26] Kestrup, Å. and Ricciardi, A. (2010) Influence of Conductivity on Life History Traits of Exotic and Native Amphipods in the St. Lawrence River. Fundamental and Applied Limnology, 176, 249-262. https://doi.org/10.1127/1863-9135/2010/0176-0249

[27] Neto, T.M.D.A., Coelho, E.F. and Silva, A.C.P. (2017) Calcium Nitrate Concentrations in Fertigation for “Terra” Banana Production. Engenharia Agricola, 37, 385-393. https://doi.org/10.1590/1809-4430-eng.agric.v37n2p385-393/2017

[28] Zhao, W., Cai, Z. and Xu, Z. (2007) Does Ammonium-Based N Addition Influence Nitrification and Acidification in Humid Subtropical Soils of China. Plant Science, 297, 213-221. https://doi.org/10.1007/s11104-007-9334-1

[29] Mccudden, C.R. (2013) pH-Adjusted Ionized Calcium. 1-5. https://acutecaretesting.org/en/articles/ph-adjusted-ionized-calcium

[30] Brugman, S.J.T., Werkhoven, B.L., Townsend, E.R., Accordini, P., van Roij, R. and Vlieg, E. (2020) Monovalent-Divalent Cation Competition at the Muscovite Mica Surface: Experiment and Theory. Journal of Colloid and Interface Science, 559, 291-303. https://doi.org/10.1016/j.jcis.2019.10.009

[31] Weil, R.R. and Brady, N.C. (2017) Soil Phosphorus and Potassium. The Nature and Properties of Soils, 2002, 643-695.

[32] Afari-Sefa, V., Kwakye, P.K., Okae-Anti, D., Imoro, A.Z. and Nyamiah, M. (2004) Potassium Availability in Soils-Forms and Spatial Distribution. The Abdus Salam International Centre for Theoretical Physics (ICTP), 40, 1-16.

[33] Kalaivani, K. and Jawaharlal, M. (2019) Study on the Physical Characterization of Coco Peat with Different Proportions of Organic Amendments for Soilless Cultivation. Journal of Pharmacognosy and Phytochemistry, 8, 2747-2749.

[34] Kumar, S., Planning, L.U., Moharana, P.C., Planning, L.U. and Meena, R.L. (2017) Assessing of Potassium Reserve and Their Relationship with Soil Properties in Western Plain of Arid India Assessing of Potassium Reserve and Their Relationship with Soil Properties in Western Plain of Arid India. International Journal of Current Microbiology and Applied Sciences, 9, 1-19.

https://doi.org/10.20546/ijcmas.2017.609.001 